\title{
Hydrodynamically Activated Sawdust of Common Pine Pinus sylvestris L.-substrate for Cultivation of the Strain GI4-16A \\ Ganoderma lucidum
}

\author{
Vladimir S. Fedorov*a, \\ Tatyana V. Ryazanovaa, Yulia A. Litovka ${ }^{a}$, \\ Igor N. Pavlov ${ }^{a, b}$, Ekaterina A. Litvinova ${ }^{a, b}$, \\ Elena A. Petrunina ${ }^{b}$, Sergey R. Loskutov ${ }^{b}$, \\ Vladimir N. Ermolin ${ }^{a}$ and Mikhail A. Bayandin ${ }^{a}$ \\ ${ }^{a}$ Reshetnev Siberian State University of Science and Technology \\ Krasnoyarsk, Russian Federation \\ ${ }^{b}$ V.N. Sukachev Institute of Forest, Russian Academy of Sciences \\ Krasnoyarsk, Russian Federation
}

Received 11.01.2022, received in revised form 21.01.2022, accepted 25.01.2022

\begin{abstract}
The results of a study on the use of sawdust of common pine Pinus sylvestris L. with their preliminary activation in a cavitation water-impact dispersant for 25 minutes as a substrate for cultivating the G14-16A strain of Ganoderma lucidum are presented. It was found that the G14-16A strain of Ganoderma lucidum colonizes the substrate more efficiently with the introduction of $\left(\mathrm{NH}_{4}\right)_{2} \mathrm{SO}_{4}$ and $\mathrm{Na}_{2} \mathrm{HPO}_{4}$ salts into its composition. At the same time, the average growth rate of basidiomycete on the substrate without the introduction of salts was $1.39 \pm 0.53 \mathrm{~mm} /$ day, and on the substrate with nitrogen salts $-3.22 \pm 0.48 \mathrm{~mm} / \mathrm{day}$, and complete fouling of the substrate occurred on day 13. It was found that during the cultivation of the G14-16A strain of Ganoderma lucidum on a substrate with nitrogen salts, the content of extractive substances in it increases from $4.37 \%$ to $6.32 \%$, where more than $65 \%$ is accounted for by substances extracted with water. There is a decrease in the content of difficult-to-hydrolyze polysaccharides by $13.3 \%$, and an increase in the non-hydrolyzable part by $2.4 \%$, which is $6.8 \%$ per organic mass. The content of easily hydrolyzable polysaccharides (LGA) decreases by $2.4 \%$, but this change is not significant in terms of organic mass and the share of LGA both before and after bioconversion is about $15.7 \%$.

The obtained data can expand the field of use of sawdust, which is a promising direction, both in the chemical and pharmaceutical industries.
\end{abstract}

(C) Siberian Federal University. All rights reserved

This work is licensed under a Creative Commons Attribution-NonCommercial 4.0 International License (CC BY-NC 4.0).

* Corresponding author E-mail address: FedorovVladimir1996@yandex.ru 
Keywords: sawdust of Common pine, hydrodynamic activation, bioconversion, Ganoderma lucidum, growth dynamics, chemical composition.

Acknowledgements. The research was conducted under the governmental task issued by the Ministry of Education and Science of Russia for the «Technology and Equipment for the Chemical Processing of the Plant Biomass Material» project by the Plant Material Deep Conversion Laboratory (topic number FEFE-2020-0016).

Citation: Fedorov, V. S., Ryazanova, T. V., Litovka, Yu. A., Pavlov, I. N., Litvinova, E. A., Petrunina, E. A., Loskutov, S. R., Ermolin, V. N., Bayandin, M. A. Hydrodynamically activated sawdust of Common pine Pinus sylvestris L. - substrate for cultivation of the strain Gl4-16A Ganoderma lucidum. J. Sib. Fed. Univ. Chem., 2022, 15(1), 90-101. DOI: 10.17516/1998-2836-0274

\title{
Гидродинамически активированные опилки сосны обыкновенной Pinus sylvestris L. - субстрат для культивирования штамма GI4-16A Ganoderma lucidum
}

\author{
В. С. Федоров ${ }^{a}$ Т. В. Рязанова ${ }^{a}$, Ю. А. Литовка ${ }^{a,}$, \\ И.Н. Павлов ${ }^{a,}$, Е. А. Литвинова ${ }^{a,}$, Е. А. Петрунина ${ }^{\sigma}$, \\ С.Р. Лоскутов ${ }^{\sigma}$, В.Н. Ермолин ${ }^{a}$, М.А. Баяндин ${ }^{a}$ \\ ${ }^{a}$ Сибирский государственный университет науки и технологий \\ имени академика М.Ф. Решетнева \\ Российская Федераџия, Красноярск

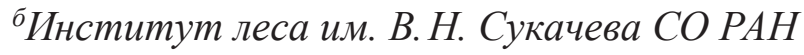 \\ ФИЦ «КНЦ СО РАН» \\ Российская Федераџия, Красноярск
}

\begin{abstract}
Аннотация. Приведены результаты исследования по использованию опилок сосны обыкновенной Pinus sylvestris L. с предварительной активацией их в кавитационном гидроударном диспергаторе в течение 25 мин в качестве субстрата для культивирования штамма G14-16A Ganoderma lucidum. Установлено, что более эффективно штамм G14-16A Ganoderma lucidum колонизирует субстрат с введением в его состав солей $\left(\mathrm{NH}_{4}\right)_{2} \mathrm{SO}_{4}$ и $\mathrm{Na}_{2} \mathrm{HPO}_{4}$. При этом средняя скорость роста

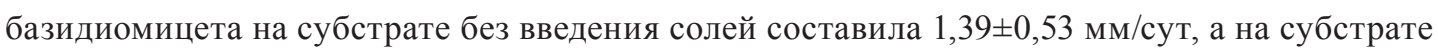
с солями азота - 3,22 \pm ,48 мм/сут, и полное обрастание субстрата происходило на 13-е сутки. Установлено, что в процессе культивирования штамма Gl4-16A Ganoderma lucidum на субстрате с солями азота в нем увеличивается содержание экстрактивных веществ с 4,37 до 6,32 \%, где более 65 \% приходится на долю веществ, экстрагируемых водой. Наблюдается снижение содержания трудногидролизуемых полисахаридов на 13,3 , и увеличение негидролизуемой части на 2,4 \%, что в расчете на органическую массу составляет 6,8 \%. Содержание легкогидролизуемых
\end{abstract}


полисахаридов (ЛГП) снижается на 2,4 \%. Однако в расчете на органическую массу это изменение не существенно и доля ЛГП как до, так и после биоконверсии составляет около 15,7 \%.

Полученные данные могут расширить область использования древесных опилок, что является перспективным направлением как в химической, так и в фармацевтической промышленности.

Ключевые слова: опилки сосны обыкновенной, гидродинамическая активация, биоконверсия, Ganoderma lucidum, динамика роста, химический состав.

Благодарности. Работа выполнена в рамках государственного задания Минобрнауки России на выполнение коллективом научной лаборатории глубокой переработки растительного сырья проекта «Технология и оборудование химической переработки биомассы растительного сырья» (Номер темы FEFE-2020-0016).

Цитирование: Федоров, В.С. Гидродинамически активированные опилки сосны обыкновенной Pinus sylvestris L. субстрат для культивирования штамма G14-16А Ganoderma lucidum / В. С. Федоров, Т. В. Рязанова, Ю. А. Литовка, И.Н. Павлов, Е. А. Литвинова, Е. А. Петрунина, С.Р. Лоскутов, В.Н. Ермолин, М. А. Баяндин // Журн. Сиб. федер. ун-та. Химия, 2022, 15(1). С. 90-101. DOI: 10.17516/1998-2836-0274

\section{Введение}

Фактический объем заготовки древесины при сплошных и выборочных рубках спелых и перестойных насаждений по Красноярскому краю в 2020 г. составил 19011,1 тыс. м³, в том числе по хвойному хозяйству $-14922,8$ тыс. м³ , по мягколиственному - 4088,3 тыс. м³ [1].

Более половины товарного круглого леса, заготовленного в России, идет на изготовление пиломатериалов и фанеры. При изготовлении пиломатериалов в среднем до 50 \% объема круглых лесоматериалов уходит в отходы, а в фанерном производстве отходы превышают половину объема лесоматериалов и достигают $65-70 \%$. Следует отметить, что около 80 \% отходов древесины при ее механической обработке остаются в химически неизменном виде - это отходы, образующиеся в производстве пиломатериалов и фанеры. Вот почему проблема комплексного использования древесины, утилизация отходов деревоперерабатывающих производств на протяжении многих лет является актуальной и требующей решения. Сферы использования таких отходов ограничиваются в основном производством топливных брикетов и пеллет, а основная масса складируется в отвалах, увеличивая техногенную нагрузку на окружающую среду [2, 3].

В то же время опилки, имея лигноцеллюлозную природу и состоящие, как и любой древесный материал, из целлюлозы, гемицеллюлозы, лигнина, экстрактивных веществ и минеральных компонентов $[4,5]$, могут быть использованы в биотехнологии, в частности в качестве сырья для производства биотоплива, витаминов, антиоксидантов, кормов для животных, антибиотиков и других потенциально важных веществ [6].

Грибы и бактерии, использующие целлюлозу в качестве источника углерода, развили сложный набор ферментов, которые гидролизуют целлюлозу, образуя мономеры глюкозы. Однако при проведении ферментативного гидролиза лигноцеллюлозных материалов в их нативном виде выход сахаров достигает менее 20 \% от теоретически возможного. Факторы, которые способствуют устойчивости растительного сырья, в частности древесного, к воздействию

$$
-92-
$$


ферментов включают высокие индекс кристалличности и степень полимеризации целлюлозы; ограниченную площадь поверхности, доступной для атаки ферментов; высокую степень экранирования целлюлозы лигнином; высокую степень «оборачивания» целлюлозы гемицеллюлозами [7].

Преодоление физико-химических барьеров, препятствующих доступности целлюлозы для ферментов, является важным вопросом, решение которого напрямую связано с поиском низкозатратных методов предварительной обработки сырья.

Предварительная обработка пентозан- и целлюлозосодержащего сырья к ферментативному воздействию заключается в деструкции лигно-углеводных связей в лигнин-гемицеллюлозной матрице, в которую заключены микрофибриллы целлюлозы, разрушении кристаллической структуры целлюлозы, разделении основных компонентов растительного сырья.

Поэтому, как показала практика, наибольший эффект может быть достигнут тогда, когда используют комплексные методы предварительной подготовки растительного сырья: механические и термохимические [8-10]; органосольвентная с получением технической целлюлозы, кислотно-катализируемая с паровым взрывом, кислотно-катализируемая с использованием дисковой мельницы и др. [11]. Выбор способа и технологических режимов подготовки сырья зависит от вида сырья и направления его использования.

Одним из наиболее перспективных методов предварительной обработки древесного сырья является гидродинамическая обработка [12]. В настоящее время для этого применяют установки гидродинамического размола $[13,14]$ и кавитационного типа [15], где в результате ударного воздействия наряду с измельчением древесных частиц происходят структурные изменения в древесном комплексе [16-20].

Проведенными ранее исследованиями установлено, что гидродинамическая обработка позволяет получать древесные частицы с большой площадью межфазных поверхностей как за счет измельчения, так и за счет фибриллирования, которое происходит вследствие частичного отделения целлюлозных фибрилл от древесных частиц. При этом появляются новые доступные межфазные поверхности с активными функциональными группами, участвующими в формировании надмолекулярных структур в древесине. Проведенные расчеты по методу Брунауэра, Эммета, Тейлора [21] показали, что удельная поверхность активированных сосновых опилок составляет около 350, а исходных - примерно $130 \mathrm{~m}^{2} / \Gamma$ абс. сухой массы. Это дает основание предположить, что гидродинамическая обработка и связанное с ней увеличение удельной поверхности древесных частиц практически 2,5 раза сделают их более доступными для микробиологического воздействия.

Оценку доступности древесного сырья для биоконверсии проводили с использованием ксилотрофных базидиальных грибов, которые широко применяют для утилизации отходов растительного происхождения, но в то же время они являются продуцентами уникального комплекса биологических активных соединений. Среди базидиомицетов особый интерес вызывает сапрофитный гриб Ganoderma lucidum, который с древних времен используется в традиционной китайской медицине и в настоящее время становится более широко известным [22]. G. lucidum существует в виде спор, мицелия и плодового тела.

Установлено, что G. lucidum обладает различными фармакологически активными веществами: белки, полисахариды, тритерпены, нуклеозиды, триглецериды и минеральные соли 
[23-26]. Эти соединения обладают ценными биоактивными свойствами, такими как антиоксидантные, антивозрастные, противовоспалительные и светозащитные эффекты, которые полезны для косметических продуктов [27]. Большинство терапевтических препаратов используют плодовое тело и мицелий G. lucidum.

Цель работы - оценить пригодность активированных опилок сосны обыкновенной (Pinus sylvestris L.) к использованию в качестве субстрата для культивирования штамма G14-16A Ganoderma lucidum и его воздействие на субстрат.

\section{Материалы и методы}

В работе исследовали опилки древесины сосны обыкновенной (Pinus sylvestris L.), которые были получены при распиловке круглых лесоматериалов (фракция $\sim 0,5$ мм).

До обработки опилки смешивали с водой из расчета концентрации опилок 10 \%. Обработку осуществляли на лабораторном гидродинамическом диспергаторе роторно-пульсационного типа: радиус ротора 277 мм, частота вращения 3000 об/мин, производительность 25 м $3 /$ в в водной среде в течение 25 мин, содержание сухих веществ в суспензии до $10 \%$ по массе [28].

Для биоконверсии субстрата использовали штамм G14-16A Ganoderma lucidum (рис. 1). Штамм G14-16А был изолирован в чистую культуру в 2016 г. из базидиомы G. lucidum (Абхазия, Сухуми). Штамм формирует хорошо развитый септированный мицелий, характерный для базидиомицетов, с многочисленными пряжками и анастомозами, толщина гиф варьирует в пределах 1,5-3,7 мкм. Отличительная особенность штамма - высокая радиальная скорость роста на агаризованных средах (до 7,9 мм/сут), что позволяет ему колонизировать стандартную чашку Петри (90 мм) в течение 7-8 сут.

Видовая идентификация подтверждена секвенированием участков генетических маркеров ITS1-ITS4 (internal transcribed spacer) с использованием оборудования ЦКП «Геномика» на базе Института химической биологии и фундаментальной медицины СО РАН, Новосибирск.

Современное систематическое положение: Fungi, Dikarya, Basidiomycota, Agaricomycotina, Agaricomycetes, Polyporales, Polyporaceae, Ganoderma, Ganoderma lucidum (Curtis) P. Karst.

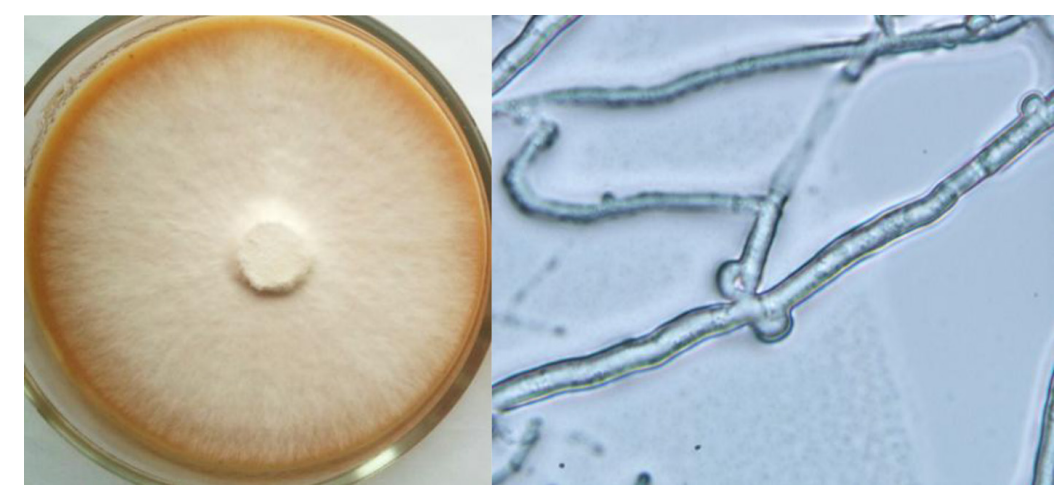

Рис. 1. Морфология колонии штамма G14-16A Ganoderma lucidum на морковном агаре на седьмые сутки (слева). Пряжки на вегетативном мицелии (справа)

Fig. 1. Morphology of a colony of the Gl 4-16A Ganoderma lucidum strain on carrot agar on the seventh day (left). Buckles on the vegetative mycelium (right) 
Твердофазное культивирование проводили на комбинированном субстрате,\% от а. с. в.: активированные сосновые древесные опилки 85, твердый остаток древесной зелени сосны после отгонки эфирных масел в качестве косубстрата и цеолит Сахаптинского месторождения в качестве структурообразователя и носителя минеральных веществ 10 и 5 соответственно. Цеолит имеет следующий минеральный состав (\% по массе): $\mathrm{SiO}_{2}-64,06-67,73 ; \mathrm{TiO}_{2}-0,21-0,45$; $\mathrm{AI}_{2} \mathrm{O}_{3}-11,00-15,55 ; \mathrm{Fe}_{2} \mathrm{O}_{3}-1,10-2,64 ; \mathrm{FeO}-0,28-1,01 ; \mathrm{MnO}-0,094-0,044 ; \mathrm{CaO}-1,78-6,66 ; \mathrm{MgO}-$ $1,34-2,30 ; \mathrm{Na}_{2} \mathrm{O}-0,54-2,59 ; \mathrm{K}_{2} \mathrm{O}-2,17-4,10 ; \mathrm{P}_{2} \mathrm{O}_{5}-0,055-0,12$.

Наилучшим для успешного культивирования микроорганизмов на растительных субстратах считается соотношение $\mathrm{C}: \mathrm{N}=25-30: 1$. Такое соотношение $\mathrm{C}: \mathrm{N}$ будет способствовать быстрому разложению органического материала с наименьшей потерей питательных веществ. Так как соотношение углерода и азота в древесине - 500: 1 - меньше оптимального [29], то в субстрат дополнительно вводили соли $\left(\mathrm{NH}_{4}\right)_{2} \mathrm{SO}_{4}$ и $\mathrm{Na}_{2} \mathrm{HPO}_{4}$ в количестве 1,0 и 0,5 г/л соответственно. Влажность в чашках Петри поддерживали в пределах 65-70 \%. Субстрат предварительно подвергали глубокому автоклавированию при 1 атм. В качестве инокулюма использовали блоки (диаметр 10 мм), вырезанные микробиологическим пробойником из зоны роста семисуточной культуры соответствующего штамма. Твердофазное культивирование осуществляли в термостате при $(23 \pm 1)^{\circ} \mathrm{C}$. Продолжительность культивирования составляла 13 суток. В процессе культивирования определяли ростовые параметры: скорость роста и ростовой коэффициент.

Для оценки биотрансформации субстрата в процессе культивирования гриба G14-16A G. lucidum изучали химический состав субстрата до и после культивирования согласно методикам, принятым в химии растительного сырья. Экстрактивные вещества определяли путем экстракции 96 \%-ным этиловым спиртом и водой. Определение содержания легкогидролизуемых полисахаридов (ЛГП) проводили $2 \%$-ной соляной кислотой, трудногидролизуемые полисахариды (ТГП) - путем обработки 80 \%-ной серной кислотой, а лигнин как остаток после ТГП $[30,31]$.

\section{Результаты и их обсуждение}

Гидродинамическая обработка опилок сосны обыкновенной на кавитационном гидроударном диспергаторе, как было установлено ранее с использованием методов термогравиметрии (ТГ/ДТГ) и растровой электронной микроскопии (РЭМ), приводит к изменениям клеточной структуры древесины сосны, в частности, если опилки до обработки выглядели как небольшие фрагменты древесины, имеющие клеточную структуру с редкими волокнистыми фрагментами, то в процессе гидродинамической обработки древесной массы чем выше степень обработки древесной массы, тем больше в ней лентообразных частиц в виде разрушенных трахеид с фибриллированными поверхностями, а это, в свою очередь, приводит к увеличению удельной поверхности частиц древесной массы со 130 у исходных до $350 \mathrm{M}^{2} / \Gamma$ абс. сухой массы у гидродинамически обработанных опилок [32].

Об этом свидетельствуют и результаты термогравиметрии сосновых опилок. Наблюдаемое смещение температурных максимумов у опилок после активации в область низких температур, по мнению авторов, связано с тем, что в процессе активации древесины происходит ее разрыхление и частичное разрушение клеточных стенок - это делает древесину менее устойчивой к воздействию низких температур [33]. 
Оценку пригодности опилок сосны обыкновенной после гидродинамической активации для использования их в качестве субстрата проводили с использованием штамма G14-16А Ganoderma lucidum. Условия культивирования штамма приведены в методической части.

О динамике колонизации сосновых опилок и кинетике роста мицелия Ganoderma lucidum можно судить по результатам, представленным на рис. 2 и 3.

На рис. 2 видно, что более эффективная колонизация штамма G14-16A Ganoderma lucidum происходит после его гидродинамической обработки с введением солей $\left(\mathrm{NH}_{4}\right)_{2} \mathrm{SO}_{4}$ и $\mathrm{Na}_{2} \mathrm{HPO}_{4}$.

3-и сутки

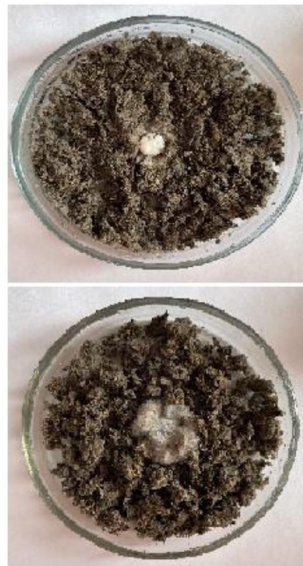

5-е сутки

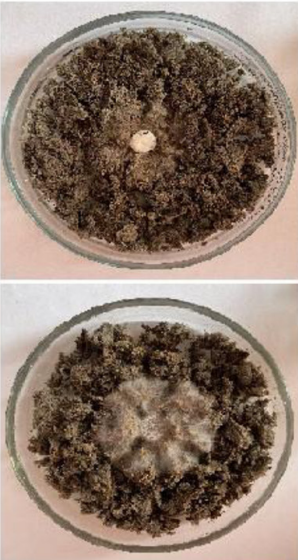

7-е сутки

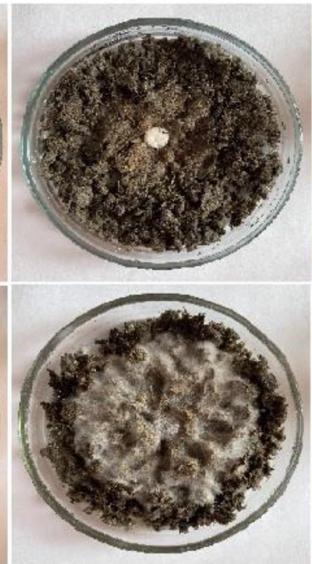

\section{3-е сутки}

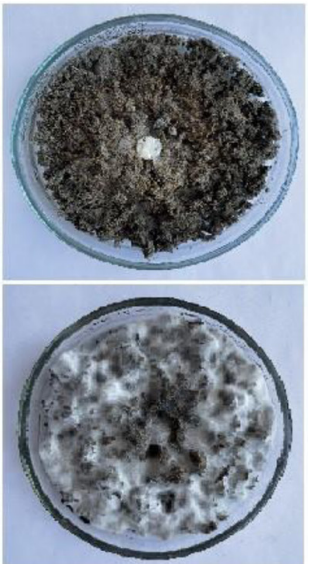

Рис. 2. Динамика роста штамма G14-16A Ganoderma lucidum на гидродинамически активированных опилках древесины сосны обыкновенной (Pinus sylvestris L.): А - необогащенные опилки; Б - опилки, обогащенные $\left(\mathrm{NH}_{4}\right)_{2} \mathrm{SO}_{4}$ и $\mathrm{Na}_{2} \mathrm{HPO}_{4}$

Fig. 2. Growth dynamics of the G14-16A strain of Ganoderma lucidum on hydrodynamically activated sawdust of Common pine (Pinus sylvestris L.): A- non-enriched sawdust; B- sawdust enriched with $\left(\mathrm{NH}_{4}\right)_{2} \mathrm{SO}_{4}$ and $\mathrm{Na}_{2} \mathrm{HPO}_{4}$

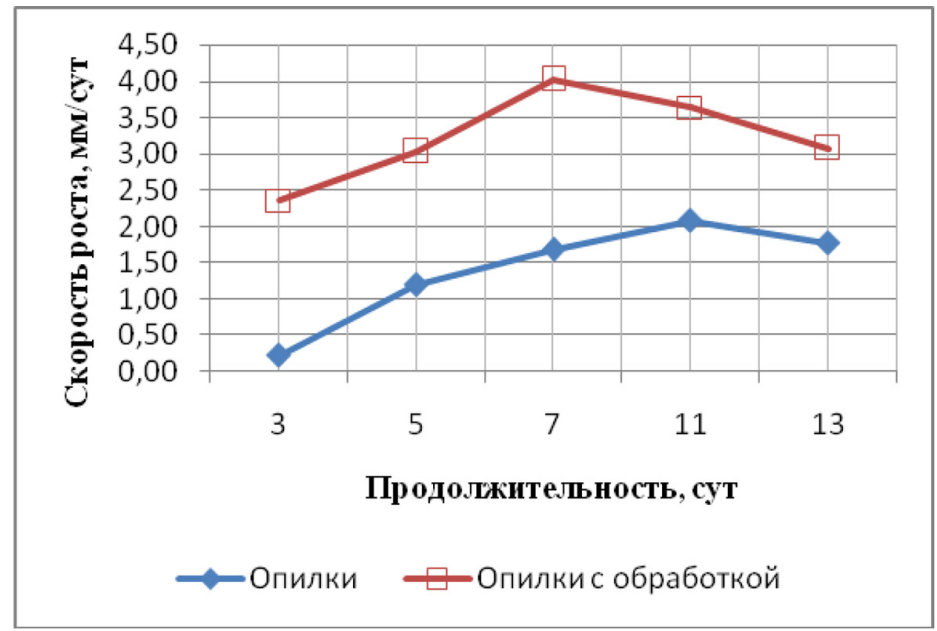

Рис. 3. Кривые скорости роста мицелия Ganoderma lucidum на субстрате из активированных сосновых опилок

Fig. 3. Curves of the growth rate of the Ganoderma lucidum mycelium on a substrate of activated pine sawdust

$$
-96-
$$


По результатам, приведенным на рис. 3 , видно, что мицелий осваивает субстрат с солями $\left(\mathrm{NH}_{4}\right)_{2} \mathrm{SO}_{4}$ и $\mathrm{Na}_{2} \mathrm{HPO}_{4}$ на 7-е сутки твердофазного культивирования при скорости роста $3,22 \pm 0,48$ мм/сут. В течение этого времени происходит накопление биомассы, и затем наступает стационарная фаза, которая характеризуется снижением скорости роста, что, по-видимому, связано с уменьшением в субстрате содержания доступных компонентов, парциального давления кислорода, увеличением плотности популяции, накоплением токсических продуктов обмена и т. п. При этом полное зарастание субстрата наблюдается на 13-е сутки. Органолептически установлено, что мицелий пушистый, разной плотности, имеет приятный, местами слабовыраженный грибной запах.

В то же время на активированном субстрате без солей колонизация субстрата происходит

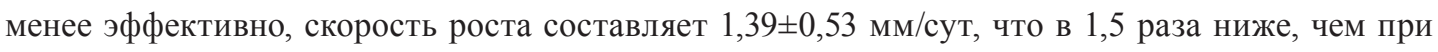
культивировании с солями азота, и стационарная фаза роста наступает на 11-е сутки.

В исследованиях, проведенных ранее [33], было показано, что гидродинамическая активация древесины сосны, оказывая заметное влияние на морфолого-анатомическое строение древесины, не изменяет структуру полимерной композиции древесинного вещества.

О том, какие изменения происходят в химическом составе субстрата с $\left(\mathrm{NH}_{4}\right)_{2} \mathrm{SO}_{4}$ и $\mathrm{Na}_{2} \mathrm{HPO}_{4}$ в результате воздействия штамма Gl4-16A Ganoderma lucidum, можно судить по результатам, приведенным в табл. 1.

Следует отметить, что наблюдаемое увеличение содержания минеральных компонентов в субстрате после культивирования исследуемого штамма связано с внесением в состав субстрата цеолита «Сахаптин» и солей $\left(\mathrm{NH}_{4}\right)_{2} \mathrm{SO}_{4}$ и $\mathrm{Na}_{2} \mathrm{HPO}_{4}$.

Результаты, приведенные в табл. 1, свидетельствуют о том, что в процессе культивирования штамма G14-16A Ganoderma lucidum на субстрате из активированных сосновых опилок в нем увеличивается содержание экстрактивных веществ с 4,37 до 6,32 \%, что в расчете на органическую массу составляет более $3 \%$, из них более 65 \% приходится на долю веществ,

Таблица 1. Изменение химического состава субстрата из опилок сосны обыкновенной под воздействием гриба Ganoderma lucidum штамм G14-16A

Table 1. Change in the chemical composition of the substrate from sawdust of Common pine under the influence of the fungus Ganoderma lucidum strain Gl4-16A

\begin{tabular}{|c|c|c|c|c|}
\hline \multirow{3}{*}{$\begin{array}{l}\text { Наименование компонента } \\
\text { Минеральные вещества }\end{array}$} & \multicolumn{4}{|c|}{ Содержание,\% а. с. в. } \\
\hline & \multicolumn{2}{|c|}{ Активированные опилки } & \multicolumn{2}{|c|}{$\begin{array}{c}\text { Субстрат } \\
\text { после биоконверсии }\end{array}$} \\
\hline & 1,69 & $-*$ & $18,18 / 17,82$ & $-*$ \\
\hline $\begin{array}{l}\text { Вещества, экстрагируемые: } \\
\text { - водой }\end{array}$ & 2,51 & $2,55^{*}$ & $4,24 / 4,15$ & $5,04^{*}$ \\
\hline - спиртом & 1,86 & $1,89 *$ & $2,21 / 2,17$ & $2,64 *$ \\
\hline Всего экстрактивных веществ & 4,37 & $4,44 *$ & $6,45 / 6,32$ & $7,69 *$ \\
\hline Легкогидролизуемые полисахариды & 15,40 & $15,66^{*}$ & $13,22 / 12,96$ & $15,77^{*}$ \\
\hline Трудногидролизуемые полисахариды & 47,94 & $48,77^{*}$ & $35,33 / 34,62$ & $42,12^{*}$ \\
\hline Негидролизуемая часть & 28,95 & $29,45^{*}$ & $32,01 / 31,37$ & $38,17^{*}$ \\
\hline
\end{tabular}


экстрагируемых водой, в составе которых присутствуют и водорастворимые минеральные вещества.

Существенные изменения наблюдаются в содержании трудногидролизуемых полисахаридов, происходит их снижение на $13,3 \%$, что составляет около $7 \%$ в расчете на органическую массу. Это изменение, по-видимому, связано с воздействием гидролитических ферментов на аморфную часть целлюлозы. Содержание легкогидролизуемых полисахаридов снижается на 2,4\%. Однако в расчете на органическую массу это изменение не существенно и доля ЛГП как до, так и после биоконверсии составляет около 16 \%. Снижение доли полисахаридов в лигно-углеводном комплексе естественно приводит к увеличению в нем содержания негидролизуемого остатка. Его содержание увеличивается на 2,4 \%, что в расчете на органическую массу составляет $6,8 \%$.

Таким образом, опилки сосны обыкновенной после гидродинамической активации могут стать перспективным сырьем для культивирования базидиомицетов, в частности Ganoderma lucidum, а оптимизация условий культивирования, включая нахождение оптимального соотношения C: N: Р, сделает этот процесс наиболее эффективным.

\section{Выводы}

Результаты исследования установили пригодность сосновых активированных опилок в качестве субстрата для биоконверсии грибом Ganoderma lucidum штамм Gl4-16А. Помимо гидродинамической обработки древесины на микробиологическую конверсию существенное влияние оказывает введение в состав субстрата солей азота, в частности $\left(\mathrm{NH}_{4}\right)_{2} \mathrm{SO}_{4}$ и $\mathrm{Na}_{2} \mathrm{HPO}_{4}$.

\section{Список литературы / References}

1. Государственный доклад «О состоянии и охране окружающей среды в Красноярском крае в 2020 году» Красноярск, 2021. 327 с. [State report «On the state and protection of the environment in the Krasnoyarsk Territory in 2020» Krasnoyarsk, 2021. 327 p. (In Russ.)]

2. Варанкина Г.С., Чубинский А.Н. Основы комплексной переработки древесного сырья. СПб.: СПбГЛТУ, 2016. 61 c. [Varankina G. S., Chubinsky A. N. Basics of complex processing of wood raw materials. St. Petersburg: SPBGTU, 2016. 61 p. (In Russ.)];

3. Аккерман А.С., Антакова В.Н.,. Бабайлов В. Е Плитные материалы и изделия из древесины. Под ред. В.И. Петри. Москва: Лесная промышленность,1976. 360 с. [Akkerman A. S., Antakova V.N., Babaylov V. E Slab materials and wood products. Under Ed. V.I. Petri. Moscow: Forest industry,1976. 360 p. (In Russ.)]

4. Pandey A., Soccol C.R., Nigam, P., Soccol V.T. Biotechnological potential of agro-industrial residues.I: Sugarcane bagasse. Bioresource Technology. 2000. 74. P. 69-80.

5. Hamelinck C.N., Van Hooijdonk G.; Faaij A.P. Ethanol from lignocellulosic biomass: Technoeconomic performance in short-, middle- and long-term. Biomass Bioenerg. 2005. 28. P. 384-410 DOI:10.1016/j.biombioe.2004.09.002

6. Sadh P. K., Duhan S., Duhan J. S. Agro-industrial wastes and their utilization using solid state fermentation: a review. Bioresources and Bioprocessing 2018, 5. DOI:10.1186/s40643-017-0187-z

7. Синицын А.П., Синицына О.А. Биоконверсия возобновляемой растительной биомассы на примере биотоплива второго поколения: сырье, предобработка, ферменты, про- 
цессы, экономика. Успехи биологической химии 2021. Т. 61. С. 347-414. [Sinitsyn A.P., Sinitsyna O.A. Bioconversion of renewable plant biomass on the example of second-generation biofuels: raw materials, pretreatment, enzymes, processes, economy. Advances in Biological chemistry 2021. Vol. 61. P. 347-414 (In Russ.)]

8. Шарков В.И., Сапотницкий С.А., Дмитриева О.А., Туманов И.Ф. Технология гидролизных производств, М., 1973. 408 с. [Sharkov V.I., Sapotnitsky S.A., Dmitrieva O.A., Tumanov I.F. Technology of hydrolysis production, Moscow, 1973. 408 p. (In Russ.)]

9. Шарков В.И., Куйбина Н.И. Химия гемицеллюлоз. М., 1972. 440 с. [Sharkov V.I., Kuibina N. I. Chemistry of hemicelluloses. Moscow, 1972. 440 p. (In Russ.)]

10. Холькин Ю.И. Технология гидролизных производств. М., 1989. 496 с. [Kholkin Yu. I. Technology of hydrolysis production. Moscow, 1989. 496 p. (In Russ.)]

11. Сушкова В.И., Устюжанина Л.В., Березина О.В., Яроцкий С.В. Методы подготовки растительного сырья к биоконверсии в кормовые продукты и биоэтанол. Химия растительного сырья 2016. 1. C. 93-119 [Sushkova V. I., Ustyuzhanina L. V., Berezina O. V., Yarotsky S. V. Methods of preparation of plant raw materials for bioconversion into feed products and bioethanol. Chemistry of vegetable raw materials 2016. 1. P. 93-119 (In Russ.)]

12. Морозов Е.А., Рязанова Т.В., Еременко О.Н. Влияние размола на полисахаридный комплекс древесины. Молодые ученые в решении актуальных проблем науки: сб. научн. док. 2010. T. 2. C. 39-43 [Morozov E. A., Ryazanova T. V., Eremenko O. N. The effect of grinding on the polysaccharide complex of wood. Young scientists in solving actual problems of science: sat. scientific doc. 2010. Vol. 2. P 39-43. (In Russ.)]

13. Алашкевич Ю. Д. Гидродинамические явления при безножевой обработке волокнистых материалов. Красноярск: СибГТУ, 2004. 80 с. [Alashkevich Yu. D. Hydrodynamic phenomena in the knife-free processing of fibrous materials. Krasnoyarsk: SibSTU, 2004. 80 p. (In Russ.)]

14. Марченко Р.А., Алашкевич Ю.Д., Решетова Н.С. Сравнительная оценка показателей размола при ножевом и безножевом способах. Химия растительного сырья 2012. 1. С. 191-198 [Marchenko R. A., Alashkevich Yu. D., Reshetova N. S. Comparative evaluation of grinding parameters in knife and knife-free methods. Chemistry of vegetable raw materials 2012. 1. P. 191-198 (In Russ.)]

15. Патент 138045 РФ. Мозговой В.Г. Кавитационный гидроударный диспергатор. Опубл. 27.02.2014. [Patent 138045 of the Russian Federation. Mozgovoy V.G. Cavitation water hammer dispersant. Publ. Date 27.02.2014 (In Russ.)]

16. Быков А. В., Мирошников С.А., Межуева Л.В. К пониманию действия кавитационной обработки на свойства отходов производств. Вестник ОГУ. 2009. 12. C. 77-80. [Bykov A. V., Miroshnikov S. A., Mezhuyeva L. V. Towards understanding the effect of cavitation treatment on the properties of industrial waste. Bulletin of OSU. 2009. 12. P. 77-80 (In Russ.)]

17. Баяндин М.А., Ермолин В.Н., Елисеев С.Г. Влияние механоактивации на аутогезионные свойства древесины. Хвойные бореальной зоны. 2013. Т. 31. 1-2. С. 159-163. [Bayandin М.А., Ermolin V.N., Eliseev S. G. The effect of mechanical activation on the autohesion properties of wood. Coniferous trees of the boreal zone 2013. Vol. 31. 1-2. P. 159-163 (In Russ.)]

18. Cervin N. T., Andersson L., Ng J.B. S., Olin P., Bergström L., Wågberg L. Lightweight and Strong Cellulose Materials Made from Aqueous Foams Stabilized by Nanofibrillated Cellulose. Biomacromolecules 2013. Vol. 14(2). P. 503-511. DOI: 10.1021/bm301755u 
19. Марченко Р.А., Алашкевич Ю.Д., Решетова Н.С. Сравнительная оценка показателей размола при ножевом и безножевом способах. Химия растительного сырья. 2012. 1. С. 191-198. [Marchenko R. A., Alashkevich Yu. D., Reshetova N. S. Comparative evaluation of grinding parameters in knife and knife-free methods. Chemistry of vegetable raw materials. 2012. 1. P. 191-198 (In Russ.)]

20. Fengel D., Wegener G. Wood: Chemistry, Ultrastructure, Reactions. Berlin, Walter de Gruyter, 1984. $613 \mathrm{p}$.

21. Ермолин В.Н., Баяндин М.А., Казицин С.Н., Намятов А.В. Формирование структуры плит малой плотности из гидродинамически активированных мягких отходов деревообработки. Лесной журнал. 2019. 5. С. 148-157. [Ermolin V.N., Bayandin M.A., Kozitsyn S.N., Namyatov A. V. Formation of the structure of low-density slabs from hydrodynamic activated soft woodworking waste. Forest Journal 2019. 5. P. 148-157 (In Russ.)]

22. Wang, P. Y., Zhu, X. L., Lin, Z. B. Antitumor and immunomodulatory e_ects of polysaccharides from broken-spore of Ganoderma lucidum. Frontiers in Pharmacology 2012, 3, 135. DOI:10.3389/ fphar.2012.00135

23. Atay S., Ak H., Kalmis E., Kayalar H., Aydin H.H. Diverse e_ects of the lingzhi or reishi medicinal mushroom, Ganoderma lucidum (Agaricomycetes), in combination with tamoxifen citrate and doxorubicin in MCF-7 breast cancer cells. International Journal of Medicinal Mushrooms 2016. 18. P. 489-499. DOI: 10.1615/IntJMedMushrooms.v18.i6.30

24. Yang, Y., Nirmagustina D. E., Kumrungsee T., Okazaki Y., Tomotake H., Kato N. Feeding of the water extract from Ganoderma lingzhi to rats modulates secondary bile acids, intestinal microflora, mucins, and propionate important to colon cancer. Bioscience, Biotechnology, and Biochemistry 2017. 81. 1796-1804 https://doi.org/10.1080/09168451.2017.1343117

25. Veena R.K., Ajith, T. A., Janardhanan K.K. Lingzhi or Reishi Medicinal Mushroom, Ganoderma lucidum (Agaricomycetes), Prevents Doxorubicin-induced Cardiotoxicity in Rats. International Journal of Medicinal Mushrooms 2017. Vol. 19 (11). P. 761-774. DOI: 10.1615/ IntJMedMushrooms.2018027010

26. Sohretoglu D., Huang S. Ganoderma lucidum polysaccharides as an anti-cancer agent. AntiCancer Agents in Medicinal Chemistry 2018. 18, 667-674. DOI: 10.2174/1871520617666171113121246

27. Abd Razak D. L., Jamaluddin A., Abd Rashid N. Y., Sani, N. A., Abdul Manan M. Assessment of Cosmeceutical Potentials of Selected Mushroom Fruitbody Extracts Through Evaluation of Antioxidant, Anti-Hyaluronidase and Anti-Tyrosinase Activity. J. 2020. 3. 329-342. https://doi. org $/ 10.3390 / \mathrm{j} 3030026$

28. Ермолин В.Н., Баяндин М.А., Казицин С.Н., Намятов А.В. Формирование структуры плит малой плотности из гидродинамически активированных мягких отходов деревообработки. Лесной журнал 2019. 5. С. 148-157 [Ermolin V.N., Bayandin M.A., Kozitsyn S.N., Namyatov A. V. Formation of the structure of low-density slabs from hydrodynamic activated soft woodworking waste. Forest Journal 2019. 5. P. 148-157 (In Russ.)]

29. Ванин С. И. Древесиноведение. Л.: Гослестехиздат, 1934. 548 с. [Vanin S. I. Wood science. Leningrad: Goslestehizdat, 1934. 548 p. (In Russ.)]

30. Оболенская А. В., Ельницкая 3. П., Леонович А. А. Лабораторные работы похимии древесиныииеллюлозы. М., 1991.320c. [Obolenskaya A. V., Yelnitskaya Z.P.,Leonovich A. A. Laboratory work on the chemistry of wood and cellulose. Moscow, 1991. 320 p. (In Russ.)] 
31. Рязанова Т.В., Чупрова Н. А., Исаева Е.В. Химия древесины:: учебное пособие в 2-х частях. Красноярск: СибГТУ, 2011, 389 с. [Ryazanova T. V., Chuprova N. A., Isaeva E. V. Chemistry of wood: a textbook in 2 parts. Krasnoyarsk: SibSTU, 2011, 389 p. (In Russ.)]

32. Ермолин В.Н., Баяндин М.А., Казицин С.Н., Намятов А.В. Формирование структуры плит малой плотности из гидродинамически активированных мягких отходов деревообработки. Лесной журнал 2019. 5. С. 148-157. [Ermolin V.N., Bayandin M. A., Kozitsyn S.N., Namyatov A. V. Formation of the structure of low-density slabs from hydrodynamic activated soft woodworking waste. Forest Magazine 2019. 5. P. 148-157. (In Russ.)]

33. Петрунина Е.А., Лоскутов С.Р., Миронов П.В. Гидродинамически активированная древесина сосны: термогравиметрия, дифференциальная сканирующая калориметрия. Строение, свойства и качество древесинь - 2018: Материалы VI Международного симпозиума имени Б. Н. Уголева, посвященного 50-летию Регионального Координационного совета по современным проблемам древесиноведения. Красноярск, 10-16 сентября 2018 г. Новосибирск: Изд-во CO PAH, 2018. C. 161-165. [Petrunina E. A., Loskutov S. R., Mironov P. V. Hydrodynamic activated pine wood: thermogravimetry, differential scanning calorimetry. Structure, properties and quality of wood-2018: Materials of the VI International Symposium named after B. N. Ugolev, dedicated to the 50th anniversary of the Regional Coordinating Council on Modern Problems of Wood Science. Krasnoyarsk, September 10-16, 2018 Novosibirsk: Publishing House of the SB RAS, 2018. P. 161-165. (In Russ.)] 